AUTHOR:

Prof Wentzel Coetzer (1)

https://orcid.org/0000-0002-3657-2997

AFFILIATION:

Departement Praktiese Teologie

Noordwes-Universiteit

CORRESPONDENCE TO:

wentzel.coetzer@nwu.ac.za

DATES:

Published: 2 December 2020

HOW TO CITE THIS ARTICLE:

Coetzer, W., 2020. Verhelderende perspektiewe vir die pastoraat

vanuit traumanavorsing rakende getraumatiseerde kinders. KOERS - Bulletin for Christian Scholarship,

85(1). Available at: https://doi.

org/10.19108/KOERS.85.1.2487

COPYRIGHT:

(c) 2020. The Author(s).

Published under the Creative Commons Attribution License.

\section{Verhelderende perspektiewe vir die pastoraat vanuit traumanavorsing rakende getraumatiseerde kinders}

\section{Opsomming}

In hierdie artikel word daar op die ingrypende langtermyn implikasies van onverwerkte trauma gedurende die kinderjare gefokus. Hierdie implikasies kan liggaamlik, emosioneel of geestelik van aard wees. Die belangrike rol van herhalende traumatiese herinneringe word vervolgens aan die orde gestel asook h aantal verdere tipiese gedragspatrone asook uitreageergedrag. Blootstelling aan die onverwerkte trauma aan die hand van verskeie blootstellingstegnieke tydens die begeleidingsproses word ook bespreek. Belangrike aspekte met betrekking tot h a antal terapeutiese strategieë kom vervolgens aan die orde terwyl moontlike pastorale implikasies deurgaans gereflekteer word. In hierdie verband word byvoorbeeld op die gebruik van hi joernaal, voorspelbare roetines en rituele, kind-gesentreerde spel, die kind se identiteit in Christus, die belangrikheid van na die kind te luister, die opstel van h tydlyn en die terapeutiese waarde van tekentake gefokus. Vanuit die resultate van navorsing op die gebied van trauma blyk uiteindelik dat daar h verskeidenheid van bruikbare komponente en perspektiewe is wat effektief deur pastorale beraders en spelterapeute in die pastorale begeleiding van getraumatiseerde kinders geinkorporeer kan word.

Kernbegrippe: Getraumatiseerde kinders, Pastoraat, Traumanavorsing

\section{Illuminating perspectives for the pastorate from trauma research on traumatized children.}

\begin{abstract}
This article focuses on the profound long-term implications of unresolved trauma during childhood. These implications can be physical, emotional or spiritual in nature. The important role of recurring traumatic memories is discussed as well as a number of further typical behavioural patterns as well as acting out behaviours. Exposure to the unresolved trauma using various exposure techniques during the counselling process is also discussed. Important aspects regarding a number of therapeutic strategies are then discussed, while also reflecting on possible pastoral implications. In this regard, for example, the focus is on the use of a journal, predictable routines and rituals, child-centred play, the child's identity in Christ, the importance of listening to the child, setting a timeline and the therapeutic value of drawing tasks.
\end{abstract}

From the results of research in the field of trauma, it eventually appears that there are a variety of useful components and perspectives that can be effectively incorporated by pastoral counsellors and pastoral play therapists into the pastoral counselling and guidance of traumatized children. Key concepts: Traumatized children; Pastorate; Trauma research

Binne God se volmaakte plan het Hy die gesin en dan ook die uitgebreide familie as 'n veilige hawe en milieu daargestel waarbinne hierdie kind veronderstel is om alles te ontvang ten einde uiteindelik tot 'n jong volwasse persoon te kan ontwikkel wat vir die uitdagings van die wêreld daar buite toegerus is. Soos wat egter vanuit die res van hierdie artikel sal blyk, het hierdie Goddelike plan in talle kinders se lewens, as gevolg van 'n 
verskeidenheid van redes, nie altyd gerealiseer nie. Talle van hierdie kinders is in ' $n$ vroeë stadium in hul lewens reeds moedeloos en talle het al 'n einde aan alles gemaak.'

\section{Metodologie}

Die basiese vertrekpunt in hierdie artikel is dié van ' $n$ literatuurstudie. ' $n$ Literatuurstudie is 'n integrale deel van navorsing (De Vos et al., 2011:123) terwyl Louw (2014) ook beklemtoon dat ' $n$ literatuurstudie tesame met kritiese beredenering en bespreking ' $n$ aanvaarbare navorsingsbenadering binne die terrein van die Praktiese Teologie is.

Nadat die probleemstelling vervolgens aan die orde gestel is, word eerstens op 'n aantal belangrike perspektiewe vanuit traumanavorsing gefokus. Daarna word ' $n$ aantal terapeutiese merkers geformuleer en ten slotte word ' $n$ aantal belangrike riglyne met betrekking tot die pastoraat aan die orde gestel.

\section{Probleemstelling}

In 'n studie waarby 90,000 tieners betrek is, het dit geblyk dat meer as $7 \%$ van hierdie groep gedurende die vorige 12 maande probeer selfmoord pleeg het (Meier et al., 2005:81). In hierdie selfde verband word gestel dat statistieke rondom selfmoord, aborsies, dwelm- en alkoholmisbruik asook ander soortgelyke negatiewe gedrag gedurende die voorafgaande 10 jaar met 75\% onder tieners toegeneem het. Verder, gebaseer op vroeëre studies, blyk dit dat, ten opsigte van al die vermelde faktore, daar 'n 300\% toename in vergelyking met 50 jaar vroeër was.

Trollinger (2007:73) haal statistieke aan wat daarop dui dat selfmoord onder tieners en jong volwassenes sedert die vyftigerjare met 60\% toegeneem het. In Suid-Afrika hou 9\% van alle tienersterftes met selfdood verband, en hierdie syfer is besig om te styg. Binne die ouderdomsgroep van 15-24 is selfdood die oorsaak van die tweede meeste sterfgevalle (SADAG, 2020).

Dit alles dui op 'n oorweldigende probleem wat tegelykertyd die noodsaaklikheid van toerusting en kennis by beraders beklemtoon ten einde in staat te kan wees om kinders wat reeds op 'n vroeë ouderdom getraumatiseer is, sinvol tot heling en emosionele balans te kan begelei.

Die klem is vervolgens op ' $\mathrm{n}$ aantal belangrike perspektiewe vanuit die traumanavorsing met betrekking tot die begeleiding van getraumatiseerde kinders.

\section{Belangrike perspektiewe vanuit traumanavorsing}

\subsection{Die belangrike bydrae van die "Adverse Childhood Experience Study (ACE)"}

Die ACE Studie het in die grootste studie van sy soort wat ooit uitgevoer is, ontwikkel. Daar was 17,000 respondente betrokke en dit het oor ' $n$ periode van 50 jaar gestrek. Hierdie studie het gevind dat 'n onverwagte hoë getal van die deelnemers (volwassenes wat na die Department of Preventive Medicine in San Diego vir ' $\mathrm{n}$ omvattende mediese ondersoek gekom het) beduidende misbruik tydens hul kinderjare ervaar het of binne'n disfunksionele huislike milieu opgegroei het (Felitti, 2002:44).

1 Wan (2019) toon aan dat vanaf 2007 tot 2017 die aantal selfdoodgevalle onder persone binne die ouderdomsgroep van 10-24 met 56\% gestyg het. 
Op grond van die resultate is ' $n$ vraelys opgestel om vervolgens enige persoon se sogenaamde ACE-telling te bepaal. Van die belangrikste bevindinge was dat in vergelyking met persone wat ' $n$ ACE telling van byvoorbeeld 0 het, was diegene met ' $n$ telling van $4 x$ of meer, twee keer meer geneig om later in die lewe rokers te wees, 12x keer meer waarskynlik dat hulle selfdood sou probeer pleeg het, 7x keer meer waarskynlik om 'n alkoholis te wees en 10x keer meer waarskynlik om straatdwelms te gebruik (Felitti, 2002:45). Gedrag wat tipies deur die gemeenskap as problematies beskou sou word, hou egter aan aangesien dit as korttermyn oplossings ${ }^{2}$ funksioneer ondanks die feit dat dit vernietigende langtermyn effekte het (Felitti et al., 1998:249).

\subsection{Trauma gedurende die kinderjare en latere fisiese probleme}

Die verbindingsfaktor tussen aftakelende kinderjare ervarings en gedrag wat ' $n$ gesondheidsrisiko tydens die volwasse jare inhou, blyk volgens Felitti et al. (1998:251) rondom aspekte soos rook, alkohol en dwelmmisbruik te sentreer (vgl. ook Hartney, 2020). Hoë vlakke van blootstelling aan aftakelende ervarings tydens kinderjare sal na verwagting ook aspekte soos angs, woede en depressie by kinders tot gevolg hê met' $n$ kritiese prys wat uiteindelik op die langtermyn betaal word. ${ }^{3}$

\subsection{Herhalende traumatiese herinneringe}

By getraumatiseerde kinders is die voorkoms van herhalende traumatiese herinneringe en oorweldigende gedagtes gewoonlik baie akuut - dit manifesteer heel dikwels ook in drome en lei tot heelwat angs en spanning. Navorsing bevestig dat dit ook dikwels tot 'n versterking van die posttraumatiese stres sindroom (PTSD) lei (Steele \& Raider, 2001:19). Getraumatiseerde kinders is gewoonlik nie in staat om emosies te gebruik as riglyne vir aksies en optredes nie omdat hulle emosioneel te oorweldig voel.

Van der Kolk et al. ${ }^{4}$ (1996:419) stel dat, as gevolg van vermelde proses, PTSD daartoe lei dat sulke kinders hul interne wêreld as 'n gevaarsone ervaar wat met traumaverwante gedagtes en gevoelens gevul is en dat dit ten alle tye vermy moet word. Die belangrikste aspek van die terapeutiese proses met sulke kinders is gevolglik om hulle te laat begryp dat hulle eintlik besig is om hul vroeëre onverwerkte ervarings te herhaal deur dit uit te reageer ${ }^{5}$. Hulle moet gevolglik gehelp word om nuwe maniere te vind om emosioneel te kan oorleef - dit vind plaas deur nuwe verbintenisse tussen hul ervarings, hul emosies en hul fisiese reaksies te plaas. Met betrekking tot hierdie kwessie maak Van der Kolk (2004:405) die volgende belangrike stelling:

Unfortunately, all too often, medications take the place of helping children acquire the skills necessary to deal with and master their uncomfortable physical sensations.

2 In hierdie verband gebruik James, Friedman \& Matthews (2002:83) die frase 'korttermyn energie ontladings-gedrag' met verwysing na die uitreageergedrag by kinders waar daar onverwerkte trauma en verliese is. By talle is daar ' $n$ magdom van pynlike emosies wat nooit verdwyn nie en wat uiteindelik ' $n$ tydbom word wat net onder die oppervlakte lê en wag vir die verkeerde stimulus om dit te sneller (vgl. ook Trollinger, 2007:53, 54, 63).

3 Aansluitend hierby is die feit dat in die verlede daar nie noodwendig altyd genoegsaam op kinders gefokus is wanneer gesinne en families deur krisisse, trauma en verliese geraak is nie. In hierdie verband word daar soms na kinders as 'the forgotten grievers' verwys (vgl. Horsley \& Patterson, 2006:131). van Boston en ook mededirekteur van die National Child Traumatic Stress Network Community Program in Boston.

5 Rothschild (2017:71) toon byvoorbeeld aan dat jong kinders geneig is om hul traumatiese ervarings uit te reageer eerder as om dit te verbaliseer. 


\subsubsection{Intervensie met behulp van blootstelling aan onverwerkte trauma}

Steele en Raider (2001:20) maak ' $n$ krities belangrike stelling wanneer hulle stel dat "... re-exposing the trauma victim to his experience has remained a core component of trauma intervention". Volgens Van der Kolk et al. (1996:420) is die mikpunt met terapie en begeleiding van die getraumatiseerde slagoffer dat traumatiese herinneringe aangepas en getransformeer moet word ten einde hul regmatige plek binne' $n$ sinvolle narratief te verkry. Wanneer die slagoffer gevolglik tydens die terapeutiese proses weer aan die oorspronklike trauma blootgestel word, is die doel van hierdie blootstelling dat die fragmente van die traumatiese ervaring hul krag gaandeweg sal verloor en dus nie weer gedrag sal sneller wat met die oorspronklike trauma verband hou nie - sodanige gedrag hou gewoonlik geensins met die teenswoordige omstandighede verband nie (vgl. ook Sinclair, 1993:58).

\subsubsection{Blootstellingstegnieke}

Indien traumatiese geheue nie geïntegreer is nie volgens die proses soos hierbo beskryf, gaan hulle steeds voort om as snellers te dien. Blootstellingstegnieke help die slagoffer egter om mettertyd te besef dat vermyding hiervan nie langer meer nodig is nie. Die vermoë om te leer hoe om die intense vrees en emosionele reaksies, gekoppel aan ' $n$ traumatiese ervaring te hanteer, is dus ' $n$ kritiese deel van die herstelproses. Korrigerende inligting moet gevolglik verskaf word sodat die slagoffer ' $n$ nuwe narratief kan vorm wat die traumatiese gebeure tot die tydsfase waarbinne dit hoort terug verplaas - die traumatiese ervaring word nou nie meer veralgemenend op elke stressituasie van elke dag toegepas nie (Steele \& Raider, 2001:21).

' $n$ Brein wat in ' $n$ permanente staat van vrees verkeer, is byvoorbeeld tipies die resultaat van ' $n$ kind wat kroniese dreigemente tydens die ontwikkelingsjare ervaar het (Perry \& Hambrick, 2008:40). Hierteenoor is dit so dat kinders wat aan konsekwente, voorspelbare, versorgende en verrykende ervarings blootgestel is, neurobiologiese vermoëns ontwikkel wat hul kanse tot gesondheid, geluk, produktiwiteit en kreatiwiteit verhoog (Brookes, 2011).

\subsubsection{Die belangrikheid van die kind se geskiedenis}

Teen bovermelde agtergrond is dit van kritiese belang om deeglike insig in die kind se ontwikkelingsagtergrond te verkry. Hier gaan dit veral om die "key insults, stressors and challenges present during development" (Perry \& Hambrick, 2008:40). Dit gaan verder ook oor die tydsberekening, aard en intensiteit van hierdie ontwikkelingsuitdagings, en Perry en Hambrick (2008:40) verwys in hierdie verband ook na die 'developmental load' wat so kind uiteindelik met hom/haar kon saamgedra het en wat vervolgens geïdentifiseer moet word.

\subsubsection{Die belangrikheid van he veilige omgewing met sinvolle verhoudings}

Daar moet vervolgens ook op al die huidige verhoudings waarbinne die kind hom/haarself bevind gefokusword. Daaris gewoonliksigbarevordering by kindersmetstabieleverhoudings en by wie daar ook ' $n$ verskeidenheid van gesonde en positiewe volwassenes betrokke is (Clark \& Henslin, 2007:193). By kinders wie se lewensomstandighede egter voortdurend aan die verander is, by wie daar chaotiese en onvoorspelbare gesinsverhoudings bestaan asook ' $n$ gebrek aan ander goeie verhoudings is, is daar in die algemeen nie vordering nie, selfs al sou hulle aan die beste terapieë blootgestel wees. "The healing environment is a safe relationally enriched environment" (Perry \& Hambrick, 2008:43; vgl. ook Herman, 1997:155).

Die psigiater, dr Bessel van der Kolk, maak die stelling dat trauma, wat mishandeling en verwaarlosing tydens kinderjare sou kon insluit, waarskynlik die enkele grootste gesondheidsuitdaging in die VSA is. Vanuit die duisende kinderslagoffers wat jaarliks aangemeld word, blyk dit dat meeste gevalle hul oorsprong tuis het. "The vast majority of people (about 80\%) responsible for child maltreatment are children's own parents" (Van der Kolk, 2004:402). 


\subsubsection{Die belangrike invloed van gesinsverhoudinge met betrekking tot die latere hantering van trauma}

Die kwaliteit van ' $n$ kind se verbintenis aan ouers en belangrike ander volwassenes bepaal grootliks die latere neuropsigologiese risikovlak wanneer hierdie kind aan trauma blootgestel word - die mate waarin hulle dus in staat is om die stres en spanning, as gevolg van die trauma, te hanteer (Rasmussen, 2012:71; Gingrich, 2020:61). In hierdie verband verwys Siegel en Payne Bryson (2018:82) na die vestiging van veerkragtigheid (resilience) by so kind. Verder het dit ook ' $n$ invloed op hul latere vermoëns om intieme verhoudings te vestig en te handhaaf.

A secure attachment with a primary caregiver allows the infant to develop the neurological connections that will eventually allow the child to regulate their own affective states (Creeden, 2006:400).

\subsubsection{Die belangrikheid van voorspelbaarheid en kontinuiteit}

Voorspelbaarheid en kontinuïteit is krities belangrik vir ' $n$ kind ten einde ' $n$ aanvoeling en vermoë vir kousaliteit (oorsaak en gevolg) te kan ontwikkel en om ervarings te kan kategoriseer. ' $n$ Kind het nodig om kategorieë te ontwikkel ten einde in staat te wees om enige spesifieke ervaring binne 'n groter konteks te kan plaas. Slegs dan sal hy/sy in staat wees om te kan evalueer wat aan die gebeur is en uit ' $n$ verskeidenheid van opsies ' $n$ keuse kan maak wat die uitkoms van die gebeure kan bepaal. "Imagining being able to play an active role leads to problem-focused coping" (Streeck-Fischer \& Van der Kolk, 2000:915).

Wanneer professionele persone en volwassenes in die algemeen nie op die hoogte van kinders se behoefte is om by stresvolle omgewings aan te pas nie en vervolgens van sulke kinders verwag om volgens volwasse standaarde van outonomie en selfstandigheid en rasionele keuses te funksioneer, lei sulke getraumatiseerde kinders se wan-aangepaste gedrag dikwels tot weersin en verwerping deur die betrokke volwassenes as gevolg van hul onkunde. "Ignorance of this fact is likely to lead to labeling and stigmatizing children for behaviors that are meant to ensure survival" (Van der Kolk, 2004:405).

Bruce Perry (2017) wat'n bekende outoriteit rakende die area van getraumatiseerde kinders is, beklemtoon in hierdie verband dat hoe meer die berader op die hoogte ten opsigte van binding en bindingsprobleme (attachment problems), normale ontwikkeling en ook abnormale ontwikkeling is, hoe meer gaan hy/sy in staat wees om die korrekte intervensies toe te pas ten opsigte van gedrag en nie problematiese gedrag verkeerd interpreteer nie.

\subsubsection{Interaksie met getraumatiseerde kinders moet in ooreenstemming met hul emosionele ouderdom plaasvind}

Kinders wat mishandel, misbruik en verwaarloos is, se emosionele en sosiale ontwikkeling sal dikwels vertraag gewees het. Wanneer hulle ook al gefrustreerd is of vrees beleef, sal daar heel moontlik ook regressie plaasvind. Dit impliseer dat op enige gegewe moment kan 'n tien jaar oue kind emosioneel soos ' $n$ tweejarige reageer. Dit is die tye wanneer daar interaksie volgens hul emosionele vlak met hulle toegepas moet word en waar enige komplekse verbale argumente met betrekking tot die gevolge van hul onvanpaste gedrag geensins produktief sal wees nie (Perry, 2017).

\subsubsection{Wees konsekwent, voorspelbaar en herhalend (repetitive)}

Mishandelde kinders met bindingsprobleme is uiters sensitief ten opsigte van veranderinge rakende skedules, nuwe oorgange, verrassings, chaotiese sosiale situasies en basies enige nuwe situasie. Dit alles kan deur sulke kinders as wanordelik, oorweldigend en verwarrend beleef word. As gevolg van hierdie redes moet alle pogings aangewend word om die reëls 
en daaglikse roetines van sulke kinders deurgaans konsekwent, voorspelbaar en herhalend toe te pas - dit dra grootliks daartoe by dat sulke kinders gevoelens van veiligheid en sekuriteit ervaar (Perry, 2017).

\subsubsection{Die rol van trauma eggo's}

Rasmussen (2012:66) beskryf trauma eggo's as boodskappe vanaf die oortreder deur wie hierdie kind êrens in die verlede getraumatiseer en/of geviktimiseer is. Hierdie boodskappe is in die onderbewussyn geregistreer en binne teenswoordige situasies waar daar ' $n$ ooreenkoms met die oorspronklike traumatiese situasie is, 'hoor' die slagoffer as't ware weer dieselfde boodskap en herbeleef hulle die ervaring weer. Hierdie trauma eggo's is geneig om die slagoffer se denke te beïnvloed en kan tot wan-aangepaste prosesse van selfdestruktiewe en/of aftakelende (abusive) gedrag teenoor hulself of ander aanleiding gee.

Die trauma eggo's tesame met die denkfoute wat daaruit voortspruit, kan verhinder dat die betrokke individu verantwoordelikheid vir hul eie gedrag aanvaar en dit kan ook die momentum van 'n potensiële genesingsproses blokkeer (Rasmussen, 2012:67). Ongelukkig is dit so dat stukkende ouers wie se eie emosionele verwonding sedert hul jeugjare nooit hanteer is nie, dikwels verantwoordelik vir bykomende skade in hierdie verband is.

\section{4. h Aantal belangrike terapeutiese strategieë}

Teen die agtergrond soos in die voorafgaande bespreking geskets, word daar vervolgens op enkele belangrike terapeutiese strategieë in die begeleiding van die getraumatiseerde kind gefokus.

\subsection{Die gebruik van 'n joernaal}

Die terapeutiese waarde van in 'n joernaal skryf, word in die literatuur sterk beklemtoon (vgl. Kraft, 2019; Ackerman, 2020; Purcell, 2016; Schupp, 2004:90).

Die beradene word aangemoedig om te skryf soos wat hulle sou praat. Hulle kan selfs in dialoogvorm oor'n gesprek met iemand skryf wat nog lewe of reeds oorlede is en wat'n groot impak op hul lewens gehad het. Dit is 'n kragtige wyse om die goeie en minder goeie tye in herinnering te roep en selfs tot ' $n$ groot mate verwerking van konflikte en onafgehandelde sake te ervaar. Perschy, (2004:67) beskryf die impak hiervan soos volg: "... a powerful asset in acknowledging, naming, expressing one's innermost thoughts and feelings, honoring them, and moving through them" (vgl. ook Jacobson, 1990:5).

\subsection{Die vestiging van voorspelbare roetines en rituele}

Kinders wat deur gekompliseerde trauma geraak is, het hulself gewoonlik binne 'n chaotiese en onvoorspelbare omgewing bevind wat alles tot ' $n$ toestand van vrees en verlies van kontrole bygedra het. Sorgdraers en terapeute vervul gevolglik 'n essensiële rol in die vestiging van ' $n$ sin van veiligheid en sekuriteit deur die vestiging van voorspelbare roetines en rituele in sulke kinders se lewens (Arvidson et al., 2011:42).

Die liefde en passie vir kinders is 'n voorvereiste om met hulle te kan werk. Indien dit vir die berader moeilik is om tot op die vlak van 'n kind te kan daal en dit ook moeilik vind om hul terminologie dienooreenkomstig aan te pas, gaan hulle moeilik tot hierdie kind deurdring en ook moeilik terapeutiese deurbrake behaal (Brookes, 2011).

\subsection{Die belangrikheid van kind-gesentreerde spel}

Blootstelling aan trauma kan die kind se normale ontwikkelingsgang ontwrig aangesien so kind gedwing word om op sy/haar fisiologiese en emosionele oorlewing te fokus (Arvidson et al., 2011:44). Die gebruik van kindgesentreerde spel wat binne 'n bindingsverhouding (attachment relationship) ingebed is, kan'n belangrike rol in die ontwikkeling van kompetensie 
en innerlike vermoëns by sulke jong kinders vervul wat met vermelde leemtes worstel. Spel is die primêre wyse waardeur jong kinders hul innerlike ervarings kommunikeer, waardeur hulle ontwikkelingstake bemeester en waardeur hulle ook die innerlike self reguleer. Verder bied dit ook aan hulle die geleentheid om te leer hoe om probleme op te los (Arvidson et al., 2011:44; Goldman, 2001:112).

\subsection{Die berader/sorgdraer as h́ spieël vir die ontwikkeling van identiteit}

Die ontwikkeling van 'n positiewe self word deur die sorgdraer ondersteun wat sekere positiewe kenmerke by die kind identifiseer, daaroor reflekteer en dan aan die kind bevestig dat hy/sy effektief en bekwaam is. Sodoende beleef die kind 'n navigeerbare en voorspelbare wêreld waarbinne hulle suksesvol voel. Die sorgdraer dien ook as 'n spieël vir die jong kind en reflekteer aan die kind sy/haar uitdrukkings en gevoelens terug. Deur hierdie spesiaal gefokusde verhouding ontwikkel die kind 'n sin vir beide die 'ander' en die 'self' (Arvidson et al., 2011:45).

Talle verwaarloosde en misbruikte kinders weet nie hoe om in interaksie met ander persone te verkeer nie en ook in hierdie opsig moet die sorgdraer en die berader' $n$ rolmodel vir die kind wees en deurgaans verduidelik wat jyself besig is om te doen en ook waarom. "Become a play-by-play announcer" (Perry, 2017).

\subsection{Maak tyd om te luister en met getraumatiseerde kinders te praat}

Een van die mees produktiewe aksies met getraumatiseerde kinders is om tyd te maak om by hulle te sit, na hulle te luister en met hulle te speel. Dit is byvoorbeeld die ideale geleentheid om hulle ook ten opsigte van verskillende emosies by elke persoon te onderrig (Perry, 2017). Sulke situasies bied aan die versorger/berader die geleentheid om ope kommunikasie te fasiliteer sonder om die kind met ' $n$ oormaat van inligting of moeilike besluite en keuses te belas (Stuber \& Mesrkhani, 2001:189; Wright, 2011:342). Dit is ook belangrik om in gedagte te hou dat kinders op 'n ongekompliseerde vlak funksioneer en dat dit gevolglik meeste van die tyd ongekompliseerde metodes en benaderings is wat die maklikste tot hulle deurdring (Brookes, 2011).

Die feit dat volwassenes bereid is om te luister maak dit uiteindelik vir die kind maklik om te aanvaar dat God ook sal luister. Wanneer volwassenes nie luister nie voel God ook ver (O'Connor, 2004:46; Cloud, 2001:338).

\subsection{Terapeutiese ingrepe in ooreenstemming met die intensiteit van die trauma}

In die begeleiding van getraumatiseerde kinders sal die strategie gewoonlik deur die intensiteit van die trauma bepaal word. In hierdie verband word die volgende drie pertinente fases gewoonlik onderskei (vgl. Perry \& Hambrick, 2008:42):

- Waar die intensiteit van die trauma hoog is, soos in gevalle van gekompliseerde trauma, is vrees gewoonlik 'n baie prominente faktor. Intense en oorweldigende vrees setel gewoonlik in die breinstam en limbiese area en oor hierdie tipe emosies het die kind geen beheer nie. In sulke gevalle word herhalende liggaam-sensoriese aktiwiteite as deel van die terapie toegepas en dit kan aspekte soos die gebruik van musiek, beweging (dans), asemhalingsoefeninge, 'drumming' (tegnieke en lirieke rakende drom slaan) en terapeutiese massering insluit. Die mikpunt hier is om die kind te help om uiteindelik beheer oor selfregulering te verkry. Omdat die emosie van vrees so diep gesetel is en die kind dit self ook moeilik kan verwoord, is ' $n$ 
aksie soos gebed ook hier baie toepaslik en effektief. ${ }^{6}$ (vgl. Hawkey, 2000:9; Gibson, 1992:165).

- Sodra die berader begin bespeur dat daar vordering ten opsigte van selfregulering tydens die eerste fase (byvoorbeeld beheer oor impulsiewe emosionele response) plaasvind kan die terapeutiese werk na probleme skuif wat meer met verhoudings verband hou. Hier kan van meer tradisionele spelen kunsterapie gebruik gemaak word.

- Namate basiese interpersoonlike tegnieke en vermoëns verbeter, kan daar gaandeweg al meer na verbale, insig georiënteerde en kognitiewe terapeutiese tegnieke beweeg word.

Hierdie uiteensetting van die drie fases sluit ook nou by Siegel en Payne Bryson (2018:22) se onderskeiding tussen ' $n$ 'grondvloer' en 'n 'boonste verdieping' in die brein (om dit meer verstaanbaar te maak) aan. Die 'grondvloer' sal op die bovermelde eerste kategorie van oorweldigende emosies, wat in die meer primitiewe dele van die brein lê (breinstam en limbiese area), van toepassing wees. Die 'boonste verdieping' hou meer met die bovermelde tweede en derde kategorieë verband - dit is daardie gedeelte van die brein wat nog grootliks onder 'konstruksie' gedurende die jeugjare is en dit beheer uiteindelik ook die meer komplekse denkstrukture asook emosionele- en verhoudingsvaardighede.

Herhalende chaotiese aktiwiteite wat telkens volgens dieselfde patroon, veral gedurende sensitiewe fases van die kind se ontwikkelingsjare geskied, lei tot die skepping van chaotiese en disfunksionele patrone in die brein. Senuweesisteme kan egter deur middel van toegewyde hoeveelhede van gefokusde, herhalende en positiewe aktiwiteite verander. ' $n$ Voorbeeld van sulke herhalende intervensies, is positiewe, versorgende interaksies met betroubare maats, onderwysers en versorgers, veral vir verwaarloosde kinders wat nie voldoende senuwee en breinstimulering gehad het ten einde die kapasiteit te ontwikkel om met andere te bind nie. Die keerpunt sal eers plaasvind wanneer hul breinstam deur veilige, voorspelbare en herhalende sensoriese insette gereguleer word (Perry \& Hambrick, 2008:43).

\subsubsection{Gefokusde aktiwiteite}

Vervolgens word gelet op enkele gefokusde aktiwiteite in die begeleiding van getraumatiseerde kinders.

\subsubsection{Die opstel van in tydlyn}

Die opstel van 'n tydlyn kan getraumatiseerde kinders help om hul huidige probleme binne die konteks van hul groter lewensverhaal te plaas (Rasmussen, 2012:71; Thorpe, 2008). Die kinders word vervolgens gevra om 'n lyn op 'n stuk papier te trek en op hierdie lyn toon hulle vervolgens sekere gebeure aan - positief en negatief - wat hulle in die verlede ervaar het. Aan die onderkant van die lyn toon hulle telkens aan wat die emosies was gekoppel aan die spesifieke gebeurtenis direk bokant die lyn. 'n Opdrag soos hierdie kan grootliks bydra dat hierdie kind sy/haar viktimiserende en uitreagerende gedrag as gevolg van al die trauma van die verlede soveel beter verstaan en uiteindelik beheer daaroor verkry.

\subsubsection{Die terapeutiese waarde van teken}

Vlakke van trauma kan steeds hoog by kinders wees selfs jare na die blootstelling aan die oorspronklike traumatiese gebeure. Die teken van prente het byvoorbeeld geblyk ' $n$ besondere funksie te vervul as deel van trauma ontlonting waar sensories gebaseerde

6 Dit herinner aan die woorde van Paulus in Romeine 8:26: “... ons weet nie wat en hoe ons behoort te bid nie, maar die Gees self pleit vir ons met versugtinge wat nie met woorde gesê word nie." 
metodes geïdentifiseer is as besonder waardevol in die ontrafeling en oplossing van krisisse (Malchiodi, 2001:21; Goldman, 2001:117). Dit kon in talle gevalle ook tot 'n verandering van denkwyse met betrekking tot hulself bydra. "The change from victim thinking to survivor thinking lessened the impact of these additional traumas" (Steele \& Raider, 2001:29).

Op 'n effektiewe wyse bring tekeninge posttraumatiese kwessies na die oppervlakte en bevorder sodoende die helpende professies se vermoë om in te gryp, terwyl dit ook die effektiwiteit van die interaksie tussen die terapeut en die kind bevorder (Malchiodi, 2001:26). Waar daar pastoraal met sulke kinders gewerk word, kan sulke teken-take ook vir die berader tersaaklike insigte na vore bring - dit sou byvoorbeeld ook met vrae oor God se rol ten opsigte van die trauma verband kon hou. ${ }^{7}$

Van der Kolk en Fisler (1995) stel dat traumatiese geheue nie noodwendig in verbale formaat gestoor word nie maar eerder in somaties-sensoriese formate. Verbale tegnieke gaan dus in die algemeen baie minder effektief in die prosessering en verwerking van pynlike emosies en herinneringe wees. Nieverbale tegnieke gaan inderdaad meer effektief wees, soos die beoefening van 'n kunsvorm soos skilder of teken of spelterapie, en ook verskillende vorme van beweging soos byvoorbeeld dans.

Teen hierdie agtergrond kan daar weer eens op die effektiwiteit van 'n aksie soos gebed vir die getraumatiseerde kind gewys word - die praktyk het dikwels bevestig dat dit tot ' $n$ groot mate van innerlike kalmte en rustigheid lei en dat dit die algemene helingsproses kan bevorder (vgl. Seamands, 2001:123-162).

\section{Gevolgtrekkings en toepaslike perspektiewe met betrekking tot die pastoraat}

Vanuit die voorafgaande bespreking kan ten slotte die volgende aantal perspektiewe geïdentifiseer word wat besondere waarde vir die pastoraat kan hê:

- In die lig van die navorsing deur Dr Felitti (ACE projek) blyk dit nodig te wees dat die kind se verhaal van trauma en onverwerkte emosionele pyn geïdentifiseer en saam deurgewerk word. Angs, woede en depressie sou ook hiermee verband kan hou. Daarna moet die detail van hierdie verhaal ook stap vir stap in gebed deurgewerk word met die oog op emosionele en geestelike heling.

- $\quad$ Die effektiwiteit van gebed as deel van 'nie-verbale tegnieke' het geblyk van besondere waarde in die begeleiding van die getraumatiseerde kind te wees.

- Dit is belangrik om die kind se ontwikkelingsagtergrond te verkry ten einde al die onderskeie areas en punte te identifiseer waar hulle emosioneel verwond en kwesbaar geraak het. Hier gaan dit ook belangrik wees om enige 'trauma eggo's' by die kind te identifiseer en te hanteer. Die krag van die leuen moet in hierdie verband verduidelik word en die leuen moet met die waarheid vervang word.

- Dit het geblyk dat die vermoë om te leer hoe om intense vrees en emosionele reaksies aan ' $n$ traumatiese ervaring gekoppel te hanteer, 'n kritiese deel van die herstelproses is. In hierdie opsig kan pastorale beraders (as deel van 'n multidissiplinêre span) byvoorbeeld 'n belangrike taak vervul deur die getraumatiseerde kind se identiteit in Christus te help vestig en hom/haar te begelei ten einde God se groter plan met hul lewens raak te sien. 
- Daar moet teen 'n oormatige afhanklikheid van medikasie ten koste van gesonde introspeksie gewaak word. Bied egter aan die getraumatiseerde kind 'n veilige ruimte waar hulle hul eie traumas in volle perspektief kan kry sonder om dit weer uit te reageer.

- $\quad$ Pastorale spelterapeute kan 'n deurslaggewende rol in die ontlonting van trauma vervul deur tegnieke soos tekenopdragte, sessies by 'n sandbak, deur met klei te werk, ens. te gebruik.

- $\quad$ Die rol van die ouerhuis, die kerk, die skool en beraders as bydraende komponente tot 'n stabiele ondersteuningstruktuur van veiligheid en sekuriteit vir die jong ontwikkelende kind het geblyk van kardinale belang te wees.

- In die dissiplinering van kinders ten opsigte van onaanvaarbare gedrag moet daar seker gemaak word dat daar geen onderliggende onverwerkte trauma, depressie of angs is nie - die onaanvaarbare gedrag sou 'n uitreagering van hierdie emosies kon wees en rigiede en outoritêre dissipline sal die kind net verder traumatiseer.

- $\quad n$ Stabiele, gebalanseerde en gesonde gesin is deurslaggewend ten opsigte van die daarstel van 'n veilige milieu vir kinders ten einde gemaklik deur hul ontwikkelingsfases te kan beweeg - dit dien onder andere as teenvoeter vir latere risiko's op neuropsigologiese vlak. Die reëls en daaglikse roetines van emosioneel verwonde kinders moet ook deurgaans konsekwent, voorspelbaar en herhalend toegepas word omdat dit sekuriteit bied. In hierdie opsig kan die kerk, die pastoraat, die skool en Christen ouers ' $n$ kardinale bydrae lewer.

- Kinders moet met ' $n$ 'innerlike kaart' toegerus word waarteen hulle alles kan meet en kontrasteer. O'Connor (2004:25) verwys in hierdie verband na 'n geestelike en emosionele kompas. Ook hier kan die pastoraat rigtinggewende kontoere bied.

- $\quad$ Die liefde en passie vir kinders is 'n voorvereiste om met hulle te kan werk.

- Hoe jonger die getraumatiseerde kind is, hoe belangriker is die noodsaaklikheid van insig by die berader om nie met behulp van rasionele en insig georiënteerde metodes die kind te benader nie - eerder nieverbale tegnieke soos spel, teken, sandbak, klei, musiek, dans, gebed, ens.

- Die berader funksioneer as ' $n$ spieël vir die ontwikkeling van die getraumatiseerde kind se identiteit. In hierdie opsig is die berader dan ook 'n beelddraer van Christus en kan die getraumatiseerde kind hom/haarself teen die beeld van Christus spieël. ${ }^{8}$

- Wanneer kinders ervaar dat volwassenes werklik luister, word die weg vir hulle gebaan om uiteindelik te kan glo dat God ook sal luister.

- Wat die opstel van 'n tydlyn ten opsigte van die getraumatiseerde kind se lewe betref, kan dit vir die proses van pastorale begeleiding ook as 'n besondere hulp dien. Op hierdie wyse kan daar op elke spesifieke traumatiese situasie in die kind se lewe gefokus word en ook seker gemaak word dat dit deur gesprek en gebed hanteer word.

\section{Samevattend}

Trauma en verliese gedurende die kinderjare wat nie hanteer is nie het geblyk oorweldigende emosionele en fisiese gevolge tydens die latere lewensjare te hê. Pastorale berading kan in hierdie verband ' $n$ krities belangrike rol vervul in die identifisering hiervan en die begeleiding van beradenes. As deel van 'nieverbale metodes' wat veral effektief met betrekking tot getraumatiseerde kinders is, kan gebed ' $n$ belangrike rol vervul terwyl

8 Vergelyk in hierdie verband die woorde in 2 Korintiërs 3:18: “... Ons word al meer verander om aan die beeld van Christus gelyk te word. Die heerlikheid wat van ons uitstraal, neem steeds toe..." 
pastorale spelterapeute se rol ook onontbeerlik in hierdie proses is. Getraumatiseerde kinders moet op hierdie wyse die boodskap kry dat iemand werklik luister en dit sal hulle uiteindelik ontvanklik maak vir die gedagte dat God ook luister.

\section{Geraadpleegde Bronne}

ARVIDSON, J., KINNIBURGH, K., HOWARD, K., SPINAZZOLA, J., STROTHERS, H., EVANS, M., ANDRES, B., COHEN, C. \& BLAUSTEIN, M.E. 2011. Treatment of complex trauma in young children: development and cultural considerations in application of the ARC Intervention Model, Journal of Child \& Adolescent Trauma, 4:34-51. https://doi.org/10.1080/19361521.2011.545046.

ACKERMAN, C.E. 2020. 83 Benefits of journaling for depression, anxiety, and stress. PositivePsychology. com https://positivepsychology.com/benefits-of-journaling/ Datum van gebruik: 1 Junie, 2020.

BROOKES, T. 2011. Out of the mouths of babes: lessons learned from children in crisis. Lesing gelewer tydens die Internasionale Konferensie van die American Association of Christian Counselors in Nashville gedurende September 2011.

CLARK, J. \& HENSLIN, E. 2007. Inside a cutter's mind. Colorado Springs, Colorado: THINK.

CLOUD, H. Change your life with changes that heal. Grand Rapids, MI: Zondervan.

CREEDEN, K. 2006. Trauma and neurobiology: Considerations for the treatment of sexual behavior problems in children and adolescents. (in Longo, R.E. \& Prescott, D.S. (eds.), Current perspectives in working with sexually aggressive youth and youth with sexual behavior problems, Holyoke, MA: NEARIK Press. pp. 395-418).

DE VOS, A.S., STRYDOM, H., FOUCHÉ, C.B. \& DELPORT, C.S.L. 2011. Research at grass roots. Pretoria: Van Schaik.

DI CIACCO, J.A. 2008. The colours of grief. Understanding a child's journey through loss from birth to adulthood. London: Jessica Kingsley Publishers.

FELITTI, V.J., ANDA, R.F., NORDENBERG, D., WILLIAMSON, D.F., ALLISON, M.S., EDWARDS, V., KOSS, M.P. \& MARKS, J.S. 1998. Relationship of childhood abuse and household dysfunction to many of the leading causes of death in adults, American Journal of Preventative Medicine, 14(4):245-258. https:// doi.org/10.1016/s0749-3797(98)00017-8.

FELITTI, V.J. 2002. The relation between adverse childhood experiences and adult health: turning gold into lead. The Permanent Journal, 6(1): 44-47.

FELITTI, V.J. 2007a. Adverse childhood experiences and stress: paying the piper, ACE Reporter, 1(4):1-4.

FELITTI, V.J. 2007b. Adverse childhood experiences: lives gone up in smoke, ACE Reporter, 1(5):1-8.

GIBSON, N. \& GIBSON, P. 1992. Deliver our children from the evil one. Tonbridge, UK: Sovereign World.

GINGRICH, H.D. 2020. Restoring the shattered self. A Christian's guide to complex trauma. Downers Grove, II: IVP Academic.

GOLDMAN, L. 2001. Breaking the silence. A guide to help children with complicated grief suicide, homicide, AIDS, violence, and abuse. New York, NY: Brunner-Routledge. https://doi. org/10.4324/9781315798493.

HARTNEY, E. 2020. Why trying to numb emotional pain with drugs makes the problem worse. Verywellmind. https://www.verywellmind.com/how-can-i-stop-hurting-22422?print Datum van gebruik: 31 Mei, 2020.

HAWKEY, R. 2000. Praying for children. Chichester, UK: New Wine Press.

HERMAN, J.L. 1997. Trauma and recovery. New York, NY: BasicBooks.

HORSLEY, H. \& PATTERSON, T. 2006. The effects of a parent guidance intervention on communication among adolescents who have experienced the sudden death of a sibling. The American Journal of Family Therapy, 34:119-137. https://doi.org/10.1080/01926180500301519.

JACOBSEN, G.B. 1990. Write grief: How to transform loss through writing. Menomonee Falls, WI: McCormick \& Schilling.

JAMES, J.W., FRIEDMAN, R. \& MATTHEWS, L.L. 2002. When children grieve. London: Harper.

KRAFT, R.N. 2019. Journaling for health. Psychology Today. https://www.psychologytoday.com/za/blog/ defining-memories/201909/journaling-health Datum van gebruik: 4 Junie, 2020. 
LOUW, D.J., 2014, 'Cura animarum as cura vitae: an existential hermeneutical approach to wholeness in pastoral caregiving within the theological framework of the compassion of God', paper presented at Faculty of Theology, North-West University, Potchefstroom, 17th October, 2014.

MALCHIODI, C.A. 2001. Using drawing as intervention with traumatized children. Trauma and Loss: Research and Interventions, 1(1):21-27.

MEIER, P.D., CLEMENTS, T., BERTRAND, J. \& MANDT, D. 2005. Blue genes. Wheaton, II: Tyndale House Publishers, Inc.

O'CONNOR, J. 2004. Children and grief. Helping your child understand death. Grand Rapids, MI: Revell.

PERRY, B.D. 2017. Bonding and attachment in maltreated children: How you can help http://teacher. scholastic.com/professional/bruceperry/bonding_help.htm Datum van gebruik: 16 Maart 2017.

PERRY, B.D. \& HAMBRICK, E.P. 2008. The neorosequential model of therapeutics. Reclaiming Children and Youth, 17(3):38-43.

PERSCHY, M.K. 2004. Helping teens work through grief. New York, NY: Brunner-Routledge.

PURCELL, M. 2016. The health benefits of journaling. https://psychcentral.com/lib/the-health-benefitsof-journaling/ Datum van gebruik: 1 Junie, 2020.

RASMUSSEN, L.A. 2012. Trauma outcome process assessment (TOPA) model: an ecological paradigm for treating traumatized sexually abusive youth, Journal of Child \& Adolescent Trauma, 5:63-80. https://doi.org/10.1080/19361521.2012.646645.

ROTHSCHILD, B. 2017. The body remembers. The psychophysiology of trauma and trauma treatment. New York, NY: W.W. Norton \& Company.

SEAMANDS, D.A. 2001. Healing of memories. Carlisle, Cumbria, UK: Alpha.

SIEGEL, D. \& PAYNE BRYSON, T. 2018. The yes brain child. New York, NY: Simon \& Schuster.

SINCLAIR, N.D. 1993. Horrific traumata. A pastoral response to the post-traumatic stress disorder; New York, NY: The Haworth Pastoral Press. https://doi.org/10.4324/9781315783611.

STEELE, W. \& RAIDER, M. 1998. Structured sensory intervention for traumatized children, adolescents, and parents. Trauma and Loss: Research and Interventions, 1(2):18-30.

STREECK-FISCHER, A. \& VAN DER KOLK, B.A. 2000. Down will come baby, cradle and all: Diagnostic and therapeutic implications of chronic trauma on child development. Australian and New Zealand Journal of Psychiatry, 34:903-918. https://doi.org/10.1080/000486700265.

SADAG. 2020.The South African Depression and Anxiety Group. Curbing teen suicide in South Africa. http://www.sadag.org/index.php?option=com content\&view=article\&id=816:curbing-teen-suicidein-south-africa\&catid=94\&Itemid=132 Datum van gebruik: 26 Mei, 2020.

SCHUPP, L.J. 2004. Assessing and treating trauma and PTSD. Eau Claire, WI: PESI.

STUBER, M.L. \& MESRKHANI, V.H. 2001. "What do we tell the children? Understanding childhood grief. Western Journal of Medicine, 174:187-191.

THORPE, C. 2008. The healing timeline: God's shalom for the past, present and future. Bellevue, WA: TimeLine Press.

TROLLINGER, S. 2007. Advanced triage counseling. Oviedo, FL: Higherlife Press.

VAN DER KOLK, B.A. 2004. Developmental trauma disorder. Psychiatric Annals, 35:5, 401-408.

VAN DER KOLK, B. A., \& FISLER, R. 1995. Dissociation and the fragmentary nature of traumatic memories: Overview and exploratory study. Journal of Traumatic Stress, 8(4), 505-525. https://doi.org/10.1002/ jts.2490080402.

VAN DER KOLK, B.A., MCFARLANE, A.C. \& WEISAETH, L. 1996. Traumatic stress: The effects of overwhelming experience on mind, body, and society. New York, NY: Guilford Press.

WRIGHT, H.N. 2011. The new guide to crisis and trauma counseling. Ventura, CA: Regal Books. 